\title{
EFFECTS OF STRATEGIC SOURCING ON ORGANIZATIONAL PERFORMANCE: A CASE OF ACACIA PREMIER HOTEL, KISUMU
}

\author{
Dr. Kimetto Richard \\ Great Lakes University of Kisumu \\ David Juma Ojino \\ Kisii University \\ Peter Njer Ayoo \\ Kisii University \\ DOI: 10.31364/SCIRJ/v7.i8.2019.P0819681 \\ http://dx.doi.org/10.31364/SCIRJ/v7.i8.2019.P0819681
}

\begin{abstract}
Business leaders continually evaluate new methods to improve the performance of their companies. They achieve these improvements by increasing revenues and decreasing costs. This study analyzes how companies can significantly increase their performance by implementing a strategic sourcing solution to reduce costs. This study was majorly concerned with the effect of strategic sourcing on organizational performance at the Acacia Premier Hotel, Kisumu. The study was guided by the following objectives; to evaluate the effect of internal sourcing on organizational performance at Acacia Premier Hotel Kisumu, to examine how outsourcing affects organizational performance at Acacia Premier Hotel, to determine the effect of single sourcing on organizational performance at Acacia premier hotel and to establish the effect of multiple sourcing on organizational performance at acacia premier hotel Kisumu. The study will be of great help to Acacia premier hotel shareholder and stakeholders at large, the researcher himself as well as other future researchers and academicians in this field of study. The study was carried out between the months of April and May 2018 and majorly covered the Acacia premier hotel Kisumu. The study employed descriptive statistics as well as a case study research design. The study took a census approach and targeted a population of 48 , made up of the staff at the Acacia premier hotel and the whole population was included in the study due to its small number. Data was collected with the use of questionnaires and secondary data was obtained from records. Reliability of the instruments was ensured by carrying out a pilot study. Data analysis was done through descriptive statistics while employing frequencies and percentages.
\end{abstract}

\section{LIST OF ABBREVIATIONS AND ACRONYMS}

\section{CEO: Chief Executive Officer}

R\&D: Research and Development

RFI: Request for Information

RFP: Request for Proposal

SRM: Supplier Relationship Management

TCO: Total Cost of Ownership 


\section{INTRODUCTION}

\section{A. 1.0 Introduction}

This chapter is majorly concerned with the introduction to the study and the chapter will discuss the background of the study, discuss the problem statement, outline the objectives and research questions, the scope of the study, the significance of the study, and finally the limitations of the study.

\section{B. 1.1 Background of the study}

C. Organizational performance comprises the actual output or results of an organization as measured against its intended outputs Richard, (2009). Organizational performance encompasses three specific areas of firm outcomes: financial performance such as profits, return on assets, return on investment, product market performance such as sales, market share and shareholder return total shareholder return, economic value added, and financial performance e.g. shareholder returns. Organization. Performance can be improved at the operational or individual employee level usually involves processes such as statistical quality control. At the organizational level, performance improvement usually involves softer forms of measurement such as customer service surveys which are used to obtain qualitative information about performance from the viewpoint of customers while at the employee level, this is measured through job satisfaction metrics.(Vallerand,2003).

Strategic sourcing focuses on improving how companies purchase the goods and services they rely on to remain competitive. It is a cost saving measure that can dramatically improve performance by exerting downward pressure on sourcing costs. The value proposition of strategic sourcing is that it enables buying organizations to obtain the highest quality of goods and services needed, with a predictable supply at the lowest total cost. Total cost is defined as more than just the cost of a good or service. It also includes ancillary costs that vary based on the buying organization's industry and the type of demand being fulfilled. Examples of these ancillary costs include: shipping, holding, and cost of capital. The results that this type of program can have on a company's bottom line are quite compelling (Krause, 2000).

Strategic Sourcing will be defined as the process of evaluating, selecting and aligning with suppliers or consortiums of suppliers to achieve operational improvements in support of an organization's strategic objectives. The phrase Strategic Sourcing was coined and is used when the activities of sourcing are directly tied to a sourcing strategy (Ellram, 2001).The most compelling aspect of the strategic sourcing value proposition is the reduction in costs for the buyer sourcing goods and services. These savings come from increased information on market pricing for products being sourced, informed supplier selection and supply aggregation. Companies leveraging a strategic sourcing process will save between $5 \%$ and $20 \%$ on all commodity types. As detailed in case studies below, these percentages can translate to hundreds of millions of shillings in savings. In addition to the direct cost savings achieved through strategic sourcing, companies that automate the Request for Quote (RFQ) creation and negotiation process find further savings in the reduction of administrative overhead and process costs associated with sourcing (Chopra, 2003).

The more critical that a particular activity is to the company's success; the more important it is to put an organization structure in place to maximize the performance of that activity. Generally, almost every business is dependent on buying goods and services. The quality, cost and delivery of goods and services directly affects the bottom line. As a result, the purchasing function has clearly emerged as an activity that is important to the success of the enterprise. Purchasing importance has been continuously growing over the last four decades. It has moved from an administrative, largely order placing function, to a strategic decision making organization that can have immediate impact on performance and revenue. It has emerged though that some companies in America and Europe are further along the purchasing evolution path than others. Recent studies suggest that over half of chief procurement officers report into a C-level executive. One only has to look at the number of articles in non-trade magazines that highlight purchasing activities to realize the growing importance of the function. Often times, the articles highlight the consequences of poor purchasing performance such as when a supplier's actions have resulted in negative consequences for the business. These types of articles highlight the fact that the sourcing and supplier management activities specifically have become important factors in the success of the enterprise. Great organizations go well beyond transactional and material acquisition 
functions. They provide advantages to their companies by transforming procurement from a transactional to a strategic focus (Freeman, 1990).

The federal government spends approximately $\$ 300$ billion on goods and services each year, and federal agencies are responsible for maximizing the value of each dollar spent. Therefore, agencies need to leverage spending to the maximum extent possible through strategic sourcing. Strategic sourcing is the collaborative and structured process of critically analyzing an organization's spending and using this information to make business decisions about acquiring commodities and services more effectively and efficiently. This process helps agencies optimize performance, minimize price, increase achievement of socio-economic acquisition goals, evaluate total life cycle management costs, improve vendor access to business opportunities, and otherwise increase the value of each dollar spent (Fine, 1998).

In Africa, With the increase of online buying and sourcing of goods and services, business managers, purchasing executives, and industry leaders have spent a great deal of time and resources attempting to improve the identification and selection of suppliers and the associated purchasing processes. Furthermore, the risks of buying the wrong items, services or from the wrong supplier can have major impacts and ripple throughout a business. Consequences can range from late delivery to total service failure liability and can even affect market competitiveness. In addition, if the selected suppliers cannot provide opportunities to reduce costs, improve and upgrade product/service offerings or provide other market-facing advantages, then an organization can quickly find itself losing market share (Daniel, 2005). Strategic sourcing in Kenya, has not thrived so much though many companies at present use strategic sourcing in their business activities with the aim of improving their business activities as well as ending up with the goods of the right quality and quantity for the sake of making maximum profits (Carr, 2000).

\section{1.2 Statement of the problem}

The aim of most businesses according to Schuh (2009) is to allow optimum performance so as to ensure that the business is kept afloat and is able to meet all its obligations at the lowest cost possible. Despite the fact that costs have to be incurred in any business venture, performance is attained through cost reduction, income optimization, operational efficiency as well as sales maximization. Many organizations in today's market are trying to meet this feat and some have resorted to strategic sourcing which involves evaluation, selection and alignment with suppliers to achieve operational improvement in support of the organization's objectives. This means that they involve suppliers in their goal of attaining performance and while some have got it right, some have not been successful in this. Despite the fact that studies have been conducted on strategic sourcing, not much has been done to relate strategic sourcing to performance. Due to this gap in information, this study therefore seeks to ascertain the effect of strategic sourcing on organizational performance taking Acacia Premier Hotel, Kisumu as a case for the study.

\section{E. 1.3 Objectives of the Study}

The study was carried out to achieve the following objectives:

i. To evaluate the effect of internal sourcing on organizational performance at Acacia Premier Hotel, Kisumu.

ii. To examine how outsourcing affects organizational performance at the Acacia Premier Hotel, Kisumu.

iii. To determine the effect of single sourcing on organizational performance at the Acacia Premier Hotel, Kisumu. To establish the effect of multiple sourcing on organizational performance at the Acacia Premier Hotel, Kisumu.

\section{F. 1.4 Research Questions}

i. What is the effect of internal sourcing on organizational performance?

ii. How does outsourcing affect organizational performance?

iii. What is the effect of single sourcing on organizational performance?

iv. What is the effect of multiple sourcing on organizational performance? 


\section{Significance of the Study}

The findings from this study are expected to shed light on the whole area of strategic sourcing and various organizations will benefit from this study as they will also get information pertaining to strategic sourcing and organizational performance.

The study will be useful to the researcher because during the research process the researcher will get to understand concepts of strategic procurement and organizational performance as well. This will widen the researcher's understanding in these two areas.

Future researchers are expected to benefit from this study because they will get information for literature review. This will make their work much easier saving them the hustle of looking for literature from very many other sources.

\section{Scope of the Study}

This study was conducted between the months of April and May 2018. The major reason for carrying out the study is to find out the effect of strategic sourcing on organizational performance.

\section{Limitations of the Study}

Limitations refer to hindrances or anticipated constraints or potential weaknesses of the study imposed by the methodology of the research. They come in the form of the things or conditions that make it difficult for the study to be conducted successfully to fully achieve the objectives.

The research was limited to the Acacia premier hotel within Kisumu town meaning that the findings got from the study may fail to represent the general position of things in the overall market. Also, being that the study was conducted in Kisumu; the findings may not be representative of the way things are in the country as a whole.

On carrying out the study, various constraints were faced by the researcher. These included lack of cooperation from the respondents, some of whom considered the researcher suspicious making them to refuse to provide the information desired. To solve this, the researcher had to request the respondents to cooperate and assure them of the purpose of the study hence asking them to give the necessary cooperation and agree to respond to the study questions.

\section{G. 1.8 Conceptual Framework}

H. Figure 1.1 Conceptual Framework

\section{Independent Variables}

Strategic Sourcing

\section{Dependent Variables}

Organizational Performance

Internal sourcing 


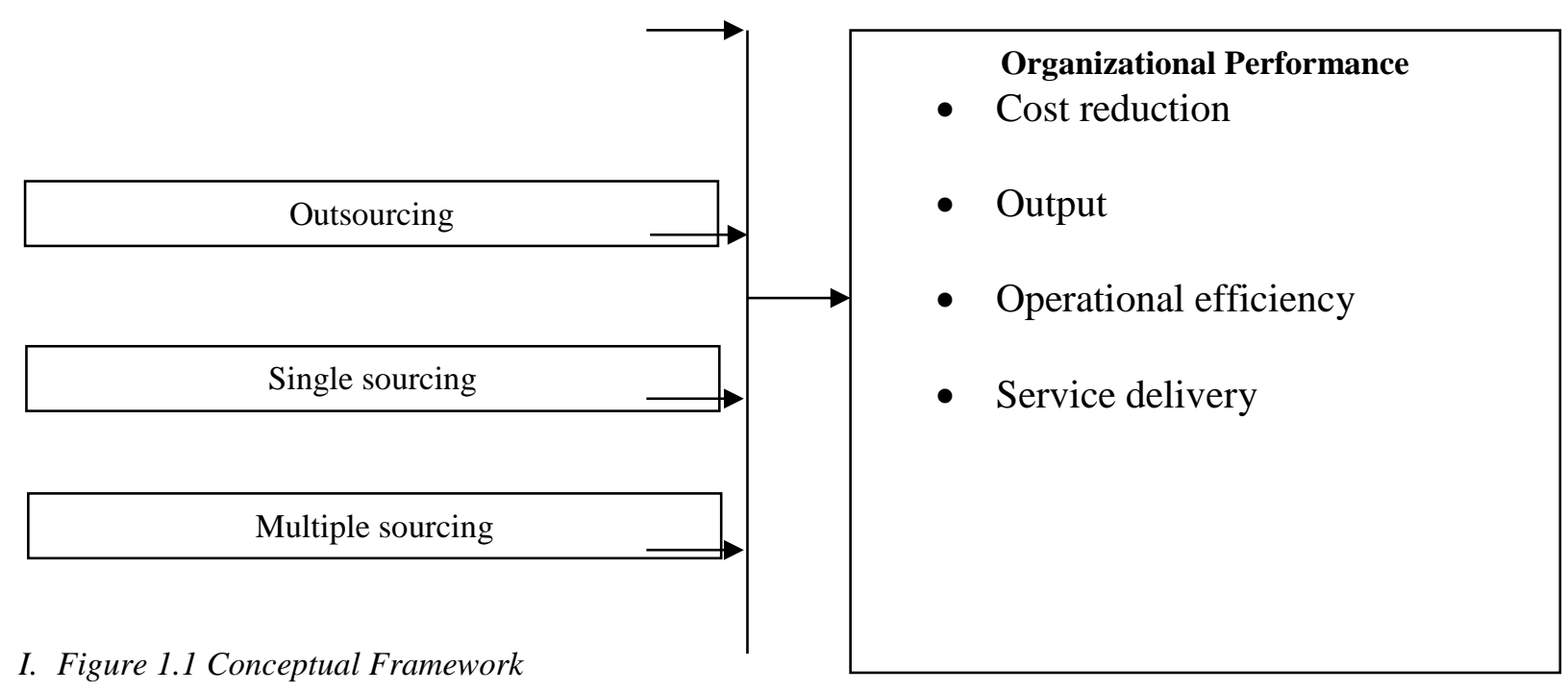

(Source: Author, 2013)

\section{CHAPTER TWO}

\section{LITERATURE REVIEW}

\section{A. 2.1 Introduction}

This chapter will be discussing the literature review of the objective of this study. It will contain information from what other researchers and scholars have already done in order to be able to facilitate this study.

\section{B. 2.2 Review of Past studies}

\section{2.2.1 Strategic sourcing}

Gerd (2005) states that Strategic sourcing is an institutional procurement process that continuously improves and re-evaluates the purchasing activities of a company. In a production environment, it is often considered one component of supply chain management. Strategic sourcing techniques are also applied to nontraditional areas such as services or capital. Also, strategic sourcing is a procurement approach that utilizes a structured, market-based process to gather data, conduct quantitative analysis and apply expert qualitative judgments to secure the best value in purchasing. Each sourcing project is unique, depending on the good or service and while the primary goal is to achieve cost savings, a total cost of ownership (TCO) methodology is applied which takes costs over the term of ownership, in addition to initial purchase. Savings are achieved by identifying and establishing the best ways to use goods or services, and by leveraging the State's substantial buying power.

The term strategic sourcing was popularized through work with a variety of blue chip companies by a number of consulting firms such as A.T. Kearney, Booz Allen Hamilton, KPMG, PricewaterhouseCoopers, and PRTM in the late 80s and early 90s. This methodology has become the norm for procurement departments in large, sophisticated companies. Cooperative sourcing is a collaboration or negotiation of different companies, which have similar business processes. To save costs, the competitor with the best production function can in-source the business process of the other competitors. This is especially common in IT-oriented industries due to low to no variable costs, e.g. banking. Since all of the negotiating parties can be outsourcers or in-sourcers the main challenge in this collaboration is to find a stable coalition and the company with the best production functions. This is difficult since the real production costs are hard to estimate and negotiators might be tempted to portray their real cost much higher than they actually are in order to demand higher fees for in sourcing. High switching costs, costs for searching potential cooperative sources and negotiating often result in inefficient solutions (Schuh, 2009). 
Many companies' external expenditures represent over $50 \%$ of gross revenues. Managing this money well is essential to delivering both the top and bottom line goals of an organization. Strategic sourcing goes beyond procurement or even skillful negotiation. In its ultimate form, strategic sourcing efforts will be a critical part of the overall organization's business strategy (Schuh, 2009).

Strategically sourcing the goods and services to support an enterprise requires an understanding of the industries you buy from, as well as a solid understanding of the industry, and how the two interact. Analyzing these industries, understanding where one's strengths lie, and determining how to leverage those strengths to deliver best value comprise the heart of a good strategic sourcing effort. Importantly, all of these must be done in the context of your overall business strategy and priorities. Essential to the execution of your sourcing strategy is the management of supplier relationships. Managed properly, these relationships can deliver value far beyond the direct supply of goods and services the supplier provides. Properly harnessed, an organization's suppliers can become a source of additional capability for an organization supplementing an organization's resources with additional market knowledge, R\&D capability, and other value-adds (Nishigushi, 1994).

Becoming the preferred customer of key suppliers in the supply chain can deliver competitive advantage in the efforts to win in the marketplace. Strategic sourcing is about more than the purchasing organization and how they interface with the markets and suppliers they buy from. The best strategic sourcing efforts include an internal component that educates the total organization in ways to interact with and derive optimum value from the supply chain. This requires more than just a skillful purchases organization. To truly embrace strategic sourcing requires a culture within the organization that engages the whole effort in the effort to incorporate optimum value from the supply chain (Daniel, 2005).

All organizations have a need for strategic sourcing. Manufacturing companies may be the most obvious candidates, but the positive impact of strategic sourcing can be tremendous for organizations as diverse as service providers, real estate firms and non-profit organizations. Ideally, strategic sourcing efforts involve more than the purchasing resources within an organization. To be the most impactful, strategic sourcing efforts must be enabled by the right culture, strong leadership, and appropriate organization design (Carr \& Smeltzer, 2000).

While strengths in these three areas will improve the strategic sourcing efforts within an organization, strategic sourcing efforts will also challenge the organization to address each of these three areas as well. Additionally, strategic sourcing, by definition, will challenge the organization to evaluate what it does best internally, what is best performed externally, and how to weave the two together in a way that maximizes value for the organization (Carr \& Smeltzer, 2000).

Because Strategic Sourcing is so comprehensive, there is a high probability that the criticality and scope of Strategic Sourcing ends up involving much more. It can result in a cross-functional/cross-enterprise effort intended to optimize the "concept-to-cash" supply chain performance. It is an ongoing endeavor to evolve both internal and external processes to obtain the highest level of strategic benefit for a business. When done correctly, the results are immense and ultimately position an organization to achieve a competitive advantage in the marketplace through its suppliers (Freeman \& Cavinato, 1990).

\section{2.2.2 Strategic sourcing process}

The Strategic Sourcing process requires an organized approach or method that allows a supply chain function to systematically work on spend areas or processes that can result in cost saving benefits. There are 8 essential steps involved in the process beginning with identifying a spend area and culminating with selecting and managing a relationship with supplier (Kannan \& Tan, 2002). All sourcing models, regardless of origin, contain the following eight essential elements: Identifying the targeted spend area; creating the sourcing team; developing a team strategy and communication plan; gathering Market Information; 
developing a supplier portfolio; developing a future state; negotiation, evaluation, commitment, and agreement; supplier relationship management

During this process, Business Unit Managers should be very careful with touch points as the touch points are very important for one to go through the whole process. Business Unit Managers are defined as any person in the organization who has an influence or is impacted by the spend area being reviewed. The process is as follows;

\section{First step; Identifying the targeted spend area}

This step involves the identification of Spend Areas that someone in the organization deems an opportunity for improvement. Usually, this is done at the CEO, CFO, or CPO level and involves selecting areas of spend that could produce cost reductions or process improvements. And one essential element needed at the outset is an Executive Sponsor to push the initiative along and keep it going. Critical to this step is prioritizing the various spend areas so that the initial areas to evaluate match the goals and objectives of the company (Freeman \& Cavinato, 1990). And it does not necessarily have to be spend areas with large volume. Identifying those areas that are common across the business units is also extremely important. If one business unit or location has a significant part of the spend activity, then perhaps a local or regional sourcing effort is more appropriate. In any event, it is critical to identify where the spend is taking place and how much activity is being accomplished throughout the business units.

\section{Second step; Creating the sourcing team}

Freeman \& Cavinato (1990) states that this step entails Creating and Developing a Sourcing Team. Most initiatives in strategic sourcing provide team members by seconding them on a part time basis. Rarely do sourcing initiatives have the luxury of having full time team members' devoted to just the sourcing effort. Regardless of method, it is important to emphasize getting departments and functions other than procurement involved. Prior to selecting the team members, it is first important to obtain Executive Sponsorship of the sourcing initiative. Having the endorsement of the highest executive level possible will pave the way for eliminating or reducing resistance from operational levels. After Executive Sponsorship has been secured, it is vital to select team members from a cross functional viewpoint. Also important are selecting cross location members to the extent that reasonableness will allow.

\section{Third step; Developing a team strategy and communication plan}

This step involves developing a Strategy on how the team will approach the identified spend area. Now that the team has been formed, the first order of business is to determine just how the team is going to accomplish the task. The team will normally develop a charter or mission statement with specific goals and objectives. Prior to finalizing the strategy in this step, the team must understand their current suppliers' capabilities and the future requirements for the commodity or service from the business units. They will identify and establish timelines and milestones as a road map to accomplish the team objectives. Finally and probably most important part of this step is for the team to develop a Communication plan that outlines how they will convey team progress and updates. Some common means of communicating this are email, written correspondence, company newsletters, intranet, and face to face dialogue. Effective and constant communication will keep the company informed and provide a key element of credibility to the project. Touch Point \#2 occurs during this step and is used to convey to the Business Unit Managers the strategy of the team. This is a continuance of keeping all decision makers and others who have influence in the particular spend area involved in the direction of the initiative (Freeman \& Cavinato, 1990).

\section{Fourth step; Gathering Market Information}


This step calls for the team to gather Market Information. Now that the strategy and current capabilities were established in step 3, it is time to find out what are the supplier capabilities in the marketplace. Interviewing key suppliers and industry leaders will produce information necessary to determine who will receive the Request for Information (RFI). Once preliminary information about the market is determined, the team will decide who should receive the RFI and the extent of how far the organization will get to the marketplace of suppliers. Typically, RFI's are designed to gather data on suppliers regarding quality programs, financial stability, service capabilities, plant locations, references from clients, organizational structure, and a mired of other than price issues. It is also a good time to send out standard terms and conditions that will eventually be employed (Gunaseram et al, 2004).

\section{Fifth step; Developing a supplier portfolio}

Requires the team to begin reviewing the completed RFI's and determining those suppliers that will be given future consideration. We call this developing the Supplier Portfolio. The team begins to develop criteria for evaluation based on the information received from the RFI's. With this information, the team will begin to identify companies that have potential to be developed either on a company-wide or regional basis. During this step, the team will decide who will receive the Request for Proposal (RFP), a step whereby the team now solicits pricing and commercial proposals from the suppliers who appear to offer the greatest potential to the sourcing initiative. Prior to sending the RFP's, the team will take the opportunity to perform Touch Point \# 3. Thus far, key management and business unit managers have been informed of strategy, plans, and objectives. Now it becomes paramount to perform this touch point because "favorite" or "preferable vendors" may not be on the list of suppliers to receive the opportunity to submit a formalized commercial proposal. This will always generate interest and comments from many of the touch point recipients. Once approval / concurrence have been established, the RFP's are sent out (Kannan \& Tan, 2002).

\section{Sixth step; Develop a Future State}

This is one of the more important steps in the entire process, Developing the "To Be State or Future State." Now that all of the RFP's are back in the hands of the team, the evaluation process entails developing a business case, performing GAP analysis, and establishing three very important and critical criteria for the team to consider when selecting the supplier(s); understanding total cost of ownership, recognizing total system cost, and developing performance metrics.

Total Cost of Ownership mentality involves the team understanding that the true cost of any product or service consist of the Acquisition Cost + Operating Cost + Maintenance Cost + training cost + warehousing cost less any salvageable value. Price is important, but not as important to the understanding of Total Cost of Ownership. This always applies in the supply chain profession. Cheaper is not always better - and the team should make their ultimate decision based on what is the best value, not lowest unit price.

Total System Cost follows the Total Cost of Ownership but is differentiated by the fact that the team also recognizes that there is a cost of doing business with the supplier base. The Total System Cost involves not only the price paid for the goods or services, but also includes the interaction costs between the company and the suppliers as well as buyer costs incurred to conduct and maintain the relationship with selected supply base. In summary, Total System Cost can be described as Supplier Costs + Supplier Profit + Interaction costs + buyer costs.

Establishing Performance Metrics with suppliers is mandatory for developing an eventual successful relationship in the long term. During the era of Purchasing Agent mentality when the most important element was a three bids and a buy process, there was not a need for performance measurement. Now that Supply Chain professionals are challenged with developing suppliers who can create value and benefit, it is also necessary to have a mechanism in place for measuring their performance. On time deliveries, warrantee issues, customer satisfaction, and quality issues are just a few of the multitude of performance metrics that need to be 
considered. Each commodity or service under review will have different metrics or criteria that are applicable to the commodity or service. The team must identify these and establish the performance review methodology prior to beginning the final selection of suppliers (Kannan \& Tan, 2002)..

The final part of this step is for the team to understand and adopt the mindset that eventual award of contract(s) involves a threephase process: Phase (i)-Selection of vendor will be based on Best Value: Phase (ii)-Continuous Improvement Objectives must be established with the supplier(s): Phase (iii)-Innovation from the selected supplier(s) will be the key to significant savings

\section{Seventh step; Negotiate, evaluate, commitment, and agree}

Involves Negotiating and Selecting Supplier(s). During this step, the team may elect to "short list" the suppliers to begin the negotiating process. Once this has been accomplished, the "short list" should be presented to the Business Unit Managers (touch point number 4) prior to notifying vendors of either their making the final stages or being eliminated from consideration. This touch point is critical in that if a favorite supplier of an influential Business Unit Manager is not selected, the team has the backup and compelling business reasons for explaining why the supplier in question was eliminated from consideration.

Very seldom does this go without controversy or conversation from Business Unit Managers and you may be forced to proceed with including suppliers the team feels does not match the credentials and qualifications necessary for final consideration. But it is much better for the sourcing effort if this is discovered at this point versus having to add a supplier to the final list after you have notified them that they are not being considered as finalists. Some points of interest that each sourcing team should adopt during the negotiating and selection stage. It takes time to develop a trust and working relationship to fully realize savings whether they be in continuous improvement processes (phase 2) or innovation (phase 3). The likelihood of significant savings comes from supplier innovation (Kruse et al, 2000).

\section{Eighth step; Supplier Relationship Management}

Is Supplier Relationship Management and Maintenance (SRM). Probably one of the most ignored portions of any strategic sourcing effort. Many times, the sourcing endeavor goes through a tremendously detailed and laborious process of vendor selection only to disband the team or not fully cultivate the relationship on both sides of the desk. To gain the significant savings from Continuous Improvement (phase 2) and Innovation (phase 3) that was established earlier in the process, only by establishing an effective SRM program will you begin to realize the savings and improvements that were initially targeted early in the sourcing process. During this step, the team should be focused on contract execution, establishing field effectiveness teams to implement new ideas or processes, developing continuous improvement cost drivers with the selected supplier(s), and refining the score cards and metrics originally developed to measure performance.

\section{E. 2.2.3 Results that can be achieved as a result of strategic sourcing}

One advantage attributed to a well-coordinated Strategic Sourcing initiative is gaining an understanding of how competencies and processes support a clearly defined business strategy. Obviously, it's impractical to meet the requirements of a business without first understanding them (Kruse et al, 2000). A Strategic Sourcing initiative presents the opportunity to clarify and communicate corporate goals and objectives. It also is a means to define and document what an organization's competencies are and what they should be. Non-value-add functions that waste critical time, resources and require financial support can be identified and outsourced or eliminated. As companies grow, many redundancies tend to occur (Ellram et al, 2002). These redundancies can be in the form of distributed activities that mirror each other, or they may take the form of similar products being itemized and purchased separately. After these redundancies are identified, aggregation of similar products or consolidation of activities can occur. The processes and workflows can also be redesigned to eliminate the non-value-added work. Ultimately, an organization 
will select its suppliers based on their ability to support and assist in improving a process, providing a product/service at a lower total cost, or offering a better product/service that helps to differentiate.

Cost reduction is typically the primary goal of most Strategic Sourcing initiatives. It is typical for businesses to spend more than 60 percent of revenue purchasing goods and services; and it is estimated that approximately 70 percent of all potential savings from purchasing can only be achieved through the Strategic Sourcing process. The results of a well-managed Strategic Sourcing initiative can be impressive and the benefits can be extended well beyond cost reduction. Impact the Bottom-line Cost reduction is typically the primary goal of most Strategic Sourcing initiatives, because savings in cost of goods sold (COGS) fall directly to the bottom-line. When properly executed, Strategic Sourcing focuses on total costs and not just the purchase price. Often, procurement professionals consider the "sticker price" versus the price of the complete lifecycle. However, other costs should also be taken into account such as carrying costs, service and repair expenses, and end-of-life/disposal costs (Carter \& Narasimhan, 1994).

\section{F. 2.2.4 Strategic Sourcing and Commodity Strategies}

Strategic sourcing is probably the most significant aspect characterizing an organization's transformation to supply management. It is also this aspect of supply management which provides some of the most value-added benefits to the organization. Sourcing, one of the major steps in the procurement process involves the identification and selection of the supplier whose costs, qualities, technologies, timeliness, dependability, and service best meet the organization's needs (Chopra \& Meindi, 2003).

Strategic sourcing involves taking a strategic approach to the selection of suppliers — an approach that is more aligned with the organization's competitive strategy. Strategic sourcing reflects the integration of procurement or sourcing strategy with corporate strategy. The integration of procurement and corporate strategy is reflective of the transformation of purchasing to supply management. One example of strategic sourcing is the commodity sourcing strategy, which focuses on developing a specific sourcing strategy for a category or group of supplies or services. This is just one application of strategic sourcing: the development and application of a carefully crafted strategy for the procurement of quality supplies and services at the lowest cost. The success of commodity strategies is based on maximizing the cost- reduction advantages of leveraging combined buying power for volume discounts, using market experts to formulate a sourcing strategy, and finally, forming strong relationships with preferred suppliers (Fine, 1998).

\section{G. 2.2.5 Strategic Sourcing approach to critical success factors}

When a sourcing professional is the first-to-know rather than the last-to-know, the sourcing function becomes proactive, instead of reactive, which significantly improves results. Consider the possible differences in costs, availability, and selection when a professional has six months to outsource a printed circuit board assembly versus three months or less because manufacturing failed to communicate capacity issues which required changes to purchasing. Consider the possible benefits when a sourcing professional has the opportunity to recognize there will be a shortage of a particular product in six months and can proactively source alternate suppliers; instead of the organization having to scramble because of missed deliveries leading to product backlogs. When executed correctly, Strategic Sourcing enables the company to constantly evaluate information about the business' strategy, overall market conditions, suppliers' performances, internal needs and expectations, and upcoming engineering changes and to adjust accordingly (Koulopoulos, 2006).

For a number of reasons, executive commitment to Strategic Sourcing is imperative. First, executives are the source of the information (business strategy objectives/operational improvement goals) and they must ensure the information is filtered to the purchasing organization. Second, the level of integration between an organization and its suppliers and the investment needed to achieve competitive advantages can be substantial and require executive commitment from all the organizations involved. Third, resources (human and financial) will have to be allocated to achieve sourcing results. Finally, and most importantly, 
organizational commitment is required to address the changes, management issues. For example, compliance to sourcing decisions often needs executive support and communications in order to drive adoption throughout the organization. An organizational commitment is required to implement and support Strategic Sourcing The expectations for a successful trading partnership will only be achieved with organizational commitment from both parties (Kannan \& Tan, 2002).

Successful Strategic Sourcing professionals will develop an understanding of their position in the marketplace: how important purchasing is relative to the whole market demand; the position or importance of suppliers in the marketplace; the balance of demand and supply, cost drivers, i.e., raw materials, manufacturing processes; new entrants into the marketplace or consolidation trends; substitutes or alternatives; and finally, suppliers' or alternate suppliers' capabilities and overall strategies. Having this understanding will help an organization be proactive to changes in the marketplace, understand ways to leverage suppliers' capabilities for lowest total cost solutions, and finally better prepare for negotiation opportunities (Freeman \& Cavinato, 1990).

Total cost analysis will indicate the types and magnitude of savings opportunities outside of traditional negotiations around price, delivery and payment terms. By understanding the impact of inventory costs, how specifications drive costs, true life-cycle costs (including warranty, repairs, and disposal), transactional costs and others, the Strategic Sourcing process can increase the value through the traditional approach and identify sources of savings when suppliers are unable or unwilling to provide price concessions (Carr \& Smeltzer, 2000).

Strategic Sourcing has traditionally been associated with consolidation opportunities. Although increased business opportunities for suppliers and perceived competition will result in delivered savings, these are typically one-time savings opportunities. However, when an organization approaches suppliers talking about strategic opportunities, looking for ways to integrate that improves the performance of both organizations, and discussing/evaluating the savings opportunities from a total cost perspective, the process becomes less contentious (James et al, 2005). Now, both parties are talking about creating value, not shifting profit from one organization to another. Likewise, technology advances such as the Internet and on-line proposal/bid processes have created competitive environments that may not previously have existed, but have caused current suppliers to be more responsive to an organization's financial objectives. However, before conducting an on-line event, it is important to understand the market characteristics to mitigate risks and prevent undesirable results. Through an understanding of strategic objectives and the marketplace, sourcing professionals can evaluate and modify supplier relationships to achieve the desired results. Strategic Sourcing has traditionally been associated with consolidation opportunities (Daniel, 2005).

One of the keys is to separate the sourcing function from the procurement function. Individuals responsible for sourcing typically spend over 50-60 percent of their days addressing transactional responsibilities (placing orders, rescheduling orders, resolving shortages, resolving invoice discrepancies) and have little time available to focus on higher value activities. Examples of higher value activities include supplier management, market research, and meeting with internal customers to understand how their needs are currently being met and/or are potentially changing. In addition, since information is required from internal customers, e.g., engineering, manufacturing, sales and marketing, potentially these individuals will be required to provide part-time support resulting in a roll change to the Strategic Sourcing process and develop an understanding of the overall business goals (Ellram et al, 2002).

Change management will be instrumental to delivering the results and more importantly sustaining the results. Change is hard. UPS Supply Chain Solutions consulting services describes this as converting from a "project" to a "process." In addition to the critical success factors mentioned above, organizational commitment, organizational role changes, and measurements (both internal and external) need to be addressed to drive the corresponding behavioral changes (Ellram et al, 2002). 


\section{H. 2.2.6 Benefits of strategic sourcing}

The tactical approach to sourcing is characterized by service models at the business or functional levels that pull in opposing directions, a lack of standardization and consequently waste of supply or purchasing leverage, and the appearance of unexpected dependencies and risks across the business. The result is a dysfunctional operating model that locks in existing inefficiencies without addressing the root causes of poor performance or the future needs of the business. One unfortunate consequence of the growth of outsourcing to encompass not only IT but also business processes and increasingly higher-value knowledge processes is that the tactical approach is becoming more prevalent. And the silo mentality that accompanies distributed organizations further exacerbates the problem (Carr \& Smeltzer, 2000).

In contrast, by connecting a company's operational base to its business aspirations, the strategic sourcing approach has two advantages. First and most important, it shifts the emphasis from short-term cost-cutting and process efficiency to a focus on the strategic change imperative and long-term value creation of the enterprise as a whole. This shift in emphasis does not mean that significant cost improvement cannot be achieved. On the contrary: the second key advantage of the strategic approach is that by creating an opportunity to identify the optimum service frame work across the company, scale economies can be maximized and more significant and sustainable cost savings delivered than via the tactical approach (Gerd, 2005).

Strategic sourcing helps organizations to; Lower spending levels, lower Total Cost of Ownership, clearly define requirements, align acquisition with mission requirements, manage vendor performance, increase achievement of socio-economic acquisition goals, increase achievement of "green" goals, improve vendor access to business opportunities.

\section{2.2.7 Single versus multiple sourcing strategy}

Single sourcing involves the idea of reducing the number of suppliers with which an organization does business, and hence sourcing from a sole source. However, according to Krause et al (2000), the concept of single sourcing has evolved with the growing popularity of the just-in-time (JIT) philosophy and many researchers have studied the advantages of this sourcing strategy".

They further pointed out that the general benefits of single sourcing include higher quality at lower total cost to the buyer and that suppliers are linked to higher levels of buyer/supplier cooperation. According to Court \& Steele (1997), moving to single sourcing will improve attitudes in both long- and short term contracts. With long-term single sourcing strategy, the supplier has the confidence to invest capital in efficiency programs and product development. The single sourcing strategy allows the supplier to stabilize staffing levels and minimize paperwork.

Multiple sourcing strategies refer to an organization having business relationships with a number of suppliers; each supplier responds to the demands and specifications of a particular quotation from the purchasing organization. The multiple-sourcing strategy plays one supplier against another and the competition among the suppliers is intense, Krause et al (2000). According to Court \& Steele (1997), the existence of a second and alternative supplier would enable the buying organization to switch demand with minimal disruption.

When several suppliers are present, since the suppliers respond to the demands and specifications of a particular quotation, the purchaser has the opportunity to receive lower prices and hence lower costs. Krause et al (2000) argued that, the suppliers has the burden of being responsible for maintaining the necessary technology, expertise, and forecasting abilities, plus cost, quality and delivery competencies. According to them, "dealing with several suppliers is likely to require longer time in negotiation and in turn, may delay or disturb production schedules". 


\section{J. 2.2.8 Performance}

Performance refers to a product's primary operating characteristics. This dimension of quality involves measurable attributes, so brands can usually be ranked objectively on individual aspects of performance. Overall performance rankings, however, are more difficult to develop, especially when they involve benefits that not every consumer needs. Performance is often a source of contention between customers and suppliers, particularly when deliverables are not adequately defined within specifications. The performance of a product often influences the performance or reputation of the end-user. As such, many contracts or specifications include damages related to inadequate performance. The question of whether performance differences are quality differences may depend on circumstantial preferences-but preferences based on functional requirements, not taste. Some performance standards are based on subjective preferences, but the preferences are so universal that they have the force of an objective standard (Chan 2002).

\section{K. 2.2.8.1 Features}

Features are additional characteristics that enhance the appeal of the product or service to the user. Similar thinking can be applied to features, a second dimension of quality that is often a secondary aspect of performance. Features are the bells and whistles of products and services, those characteristics that supplement their basic functioning. The line separating primary performance characteristics from secondary features is often difficult to draw (Chan 2002).

\section{2.2.8.2 Reliability}

Reliability is the likelihood that a product will not fail within a specific time period. This is a key element for users who need the product to work without fail. This dimension reflects the probability of a product malfunctioning or failing within a specified time period. Among the most common measures of reliability are the mean time to first failure, the mean time between failures, and the failure rate per unit time. Because these measures require a product to be in use for a specified period, they are more relevant to durable goods than to products and services that are consumed instantly. Reliability normally becomes more important to consumers as downtime and maintenance become more expensive. Reliability may be closely related to performance. For instance, a product specification may define parameters for up-time, or acceptable failure rates. Reliability is a major contributor to brand or company image, and is considered a fundamental dimension of quality by most end-users (Stukhart 1995).

\section{M.2.2.8.3 Conformance}

The dimension of conformance depicts to what extent a product's design and operating characteristics meet established standards. This dimension owes the most to the traditional approaches to quality pioneered by experts like Juran. All products and services involve specifications of some sort. When products are developed, these specifications are set and a target is set, for instance the materials used or the dimension of the product. Not only the target but also the tolerance is defined. One problem with this approach is that there is little interest in whether the specifications have been met exactly as long as the tolerance limits are met (Che Wan Putra et al. 1999).

\section{N. 2.2.8.4 Durability}

Durability measures the length of a product's life. When the product can be repaired, estimating durability is more complicated. The item will be used until it is no longer economical to operate it. This happens when the repair rate and the associated costs increase significantly. Technically, durability can be defined as the amount of use one gets from a product before it deteriorates. Durability, then, may be defined as the amount of use one gets from a product before it breaks down and replacement is preferable to continued repair. This approach to durability has two important implications. First, it suggests that durability and reliability are closely linked. A product that often fails is likely to be scrapped earlier than one that is more reliable; repair costs will be correspondingly higher and the purchase of a competitive brand will look that much more desirable. Second, this approach implies that durability figures should be interpreted with care. An increase in product life may not be the result of technical 
improvements or the use of longer-lived materials. Rather, the underlying economic environment simply may have changed (Jayashankar, 2001).

\section{O. 2.2.8.5 Serviceability}

Serviceability involves the consumer's ease of obtaining repair service, the responsiveness of service personnel, and the reliability of service. Competence and ease of repair is the speed with which the product can be put into service when it breaks down, as well as the competence and the behavior of the service personnel (Richard, 2009).

Consumers are concerned not only about a product breaking down but also about the time before service is restored, the timeliness with which service appointment are kept, the nature of dealings with service personnel, and the frequency with which service calls or repairs fail to correct outstanding problems. In those cases where problems are not immediately resolved and complaints are filed, a company's complaint handling procedures are also likely to affect customer's ultimate evaluation of product and service quality (Richard, 2009).

Some of these variables reflect differing personal standards of acceptable service. Others can be measured quite objectively. Customers may remain dissatisfied even after completion of repairs. How these complaints are handled is important to a company's reputation for quality and service. Eventually, performance is likely to be affected as well. Companies differ widely in their approaches to complaint handling and in the importance they attach to this element of serviceability. Some do their best to resolve complaints; others use legal gimmicks, the silent treatment and similar ploys to rebuff dissatisfied customers (Richard, 2009).

Important attributes for serviceability dimension are: service warranty, parts warranty, parts availability, number of reasonable distance to dealer service centers, distance to service parts center-dealer, distance to service parts center individual, length of wait for service appointment, schedule of preventive maintenance, employees listen to customers, information regarding repairs, courteous service centers, repaired correctly first time, service time relative to other dealers, warranty claims handled without argument, average repair cost/year, extended warranty, underestimation of service cost and provision of loan car (Ruffa, 2008).

The aesthetic properties of a product contribute to a company's or brand's identity. Faults or defects in a product that diminish its aesthetic properties, even those that do not reduce or alter other dimensions of quality, are often causing rejection. Aesthetics refers to how the product looks feels, sounds, tastes or smells. It is clearly a matter of personal judgment and a reflection of individual preference. Nevertheless, there appear to be some patterns in consumers' rankings of products on the basis of taste. A recent study of quality in food categories, found that high quality was most often associated with rich and full flavor, tastes natural, tastes fresh, good aroma, and looks appetizing. The aesthetics dimension differs from subjective criteria pertaining to performance in that aesthetic choices are not nearly universal. Not all people prefer "rich and full" flavor or even agree on what that means. Companies therefore have to search for a niche. On this dimension of quality, it is impossible to please everyone (Ruffa, 2008).

Perception is not always reality. The product or service may possess adequate or even superior dimensions of quality, but still fall victim to negative customer or public perceptions. Consumers do not always have complete information about a product's or service's attributes; indirect measures may be their only basis for comparing brands. A product's durability for example, can seldom be observed directly; it usually must be inferred from various tangible and intangible aspects of the product. In such circumstances, images, advertising and brand names-inferences about quality rather than the reality itself-can be critical. Reputation is the primary stuff of perceived quality. Its power comes from an unstated analogy: that the quality of products today is similar to the quality of products of yesterday, or the quality of goods in a new product line is similar to the quality of a company's established products (Dey, 2001). 


\section{RESEARCH METHODOLOGY AND DESIGN}

\section{A. 3.1 Introduction}

This chapter shall discuss the research design that was applied in carrying out the study. It shall also describe the study area to be covered in the study, together with the target population and the sampling technique to be used. The chapter shall further discuss the data collection instruments that will be used and the process of data analysis applied. The data for this study was collected through self-administered questionnaires.

\section{B. 3.2 Research Design}

The best design depends on the research question as well as the orientation of the researcher (Robson, 2003). In this research, a case study research design will be used. A case study is an in depth study of a particular situation rather than a sweeping statistical survey. It is a method used to narrow down a very broad field of research into one easily researchable topic. This design is suitable to be used because the area of interest is a single firm in which all the study is to be done.

\section{3.3 Target Population}

Target population is the people a researcher selects as respondents in the study and who are vital in achieving the set objectives (Kombo \& Tromp, 2006). This study's target population was comprised of the staff at the Acacia premier hotel, Kisumu.The population added up to 48 .

\section{3.4 Sampling Design and Sample Size}

In the study, the researcher used census method implying that the whole population took part in the study. This means that the researcher had 48 respondents taking part in the study.

\section{E. 3.5 Description of Data Collecting Instruments}

\section{F. 3.5.1 Questionnaires}

The study employed the use of questionnaires as the main tools of data collection. Questionnaires were used to collect data from the respondents. A questionnaire is a research instrument consisting of a series of questions and other prompts for the purpose of gathering information from respondents Foddy (2001).The questionnaires were preferably used because they are reliable for gathering a large amount of data at a reasonably quick pace. The data gathered using the questionnaires was coded for easy analysis.

\section{G. 3.5.2 Secondary Data from Records}

Secondary data was collected through critical examination of recorded documents that are related to the study. This enabled the researcher to obtain information that is able to shed more insight on the study. The information gathered was obtained from published journals as well as private authored materials on issues pertaining to strategic sourcing and performance.

\section{H. 3.6 Validity and Reliability of Research Instruments}

\subsubsection{Validity}

Validity is a degree to which results obtained from the analysis of the data actually represent the phenomenon under study. It is the accuracy and meaningfulness of inferences which are based on research results. Validity is quantified by comparing measurements with values that are as close to the true values as possible. Poor validity reduces the ability to characterize relationships between variables of data in research. Mugenda and Mugenda (2003), argues that validity of an instrument is demonstrated when that instrument performs its designed purpose. The research used content validity which refers to the extent to which a measure represents all facets of a given social construct. The validity was quantified through the use of experts. The researcher had experts go through the questions in the questionnaire to quantify if the questions are valid. 


\subsubsection{Reliability}

Reliability is a measure of the degree to which a research yields consistent results or data after repeated trials. It is a degree of constituency that the research instruments or procedures demonstrate. It is the reproducibility of a measurement. It is qualified by taking several measurements on the same subjects. Poor reliability degrades the precision of a single measurement and reduces the ability to track changes in measurement studies Kothari (1997). The reliability of data collection instruments was determined from a pilot study where the researcher administered the research instruments to the respondents of not included in the sample.

\section{3.7 Data Analysis}

Data analysis is the process of creating order, structure and meaning to the mass of information collected (Mugenda, 2003). The data collected was analyzed using descriptive statistics. Descriptive statistics is the discipline of quantitatively describing the main features of a collection of data which provides simple summaries about the sample and about the observations that have been made (Kombo \& Tromp, 2006). The descriptive statistics used included frequencies and percentages.

\section{CHAPTER FOUR}

\section{4.0 DATA ANALYSIS, PRESENTATION AND INTERPRETATION}

\section{A. 4.1 Introduction}

In this chapter is contained the data analysis, presentation and interpretation basing on the study findings. After data collection, data from the field was coded and edited for completeness. It was then analyzed inform of percentages through descriptive statistics and presented in frequency distribution tables. Forty eight (48) questionnaires were issued to respondents, all of which were positively responded to and returned after completion representing a return rate of $100 \%$. This kind of response indicates commitment on the side of the respondents as well as the urge to participate in the study.

\section{B. 4.2 Demographic Information}

In any study, it is very important for the researcher to ascertain the nature of the respondents included in the study. It was therefore necessary for the researcher to establish the background information of the respondents so as to know the kind of people who constituted the respondents. The demographic information in this case constituted the gender of the respondents, age bracket, the duration of time worked in the organization as well as highest level of education.

\section{4.2.1Gender of the respondents}

It was important to ascertain the gender of the respondents included in the study as this would help indicate the kind of jobs majorly done in the organization as well as their requirements. The gender of employees in an organization also indicates whether the organization follows the gender requirements in employment. The findings on employee gender are presented on the following table;

D. Table 4.1: Gender of the respondents

\begin{tabular}{|l|l|l|}
\hline Gender & Frequency & Percentage \\
\hline Male & 25 & 52.1 \\
\hline Female & & \\
\hline & 23 & 47.9 \\
\hline
\end{tabular}




\begin{tabular}{|l|l|l|}
\hline Total & 48 & 100 \\
& & \\
\hline
\end{tabular}

Source: (Researcher, 2016)

The study findings in the study indicated that the majority of the respondents were male representing $52.1 \%$ of all the respondents while $47.9 \%$ were female indicating that in the study, there were more male respondents compared to their female counterparts. This is an indication that the organization recognizes the employment laws which require that there be equal chances for both males and females in organizations. The study findings also indicate that though there is a gender difference in the organization, both genders have been kept at a satisfactory level.

\section{E. 4.2.2 Age bracket of the respondents}

In any organizational setting, age plays a very important role in the way the employees relate. Age was therefore very essential in this study so as to know the age distributions in the organization as well as the employee relation patterns. It has been ascertained also that young employees have a tendency to work in groups in most cases and also tend to relate to each other much more than their older counterparts. The study findings on age are presented on the following table;

\section{F. Table 4.2: Age bracket of the respondents}

\begin{tabular}{|l|l|l|}
\hline Age bracket & Frequency & Percentage \\
\hline $18-30$ years & 20 & 41.7 \\
\hline $31-40$ years & 19 & 39.6 \\
\hline $41-50$ years & 7 & 14.6 \\
\hline Over 50 years & & 4.2 \\
\hline Total & 2 & $\mathbf{1 0 0}$ \\
\hline
\end{tabular}

Source: (Researcher, 2016)

Basing on the findings on the table above, it is evident that $41.7 \%$ of the respondents were aged in the range of $18-30$ years, $39.6 \%$ were aged in between $31-40$ years, $14.6 \%$ of the respondents were aged between 41 and 50 years while $4.2 \%$ were over 50 years.

Following these findings, it is clear that most of the employees in the organization are aged between 18-30 years, followed by employees between 31 and 40 years, followed by employees aged 41-50 years while the least of the employees are aged over 50 years. The researcher found out that most of the employees in the organization are aged below 40 years compared to those aged above 40 years. This indicates that most of the employees are either youths or just a few years past the youth age.

\section{G. 4.2.3 Duration of time worked for the organization}

The researchers deemed it important to find out the duration of time in years that the employees had worked for the ministry. This would be important in knowing the level of experience the employees had in the operations of the organization. This information is presented on the table following; 
H. Table 4.3: Duration of time worked for the company

\begin{tabular}{|l|l|l|}
\hline Years & Frequency & Percentage \\
\hline Less than 2 years & 13 & 27.1 \\
\hline Between 2 and 5 years & 29 & 60.4 \\
\hline Over 5 years & 6 & 12.5 \\
\hline Total & & $\mathbf{1 0 0}$ \\
\hline
\end{tabular}

Source: (Researcher, 2016)

The table relays the findings on the length of time in years the employees have worked in the organization. Basing on the findings, $27.1 \%$ of the respondents have worked for the organization for less than 2 years, $60.4 \%$ have worked for between 2 and 5 years, and $12.5 \%$ have worked there for over 5 years. Generally, most of the employees in the organization have worked for between 2 and 5 years while a very small percentage have worked for more than 5 years indicating that a high number of the employees within the ministry have not served for long. Those who have worked for more than 1 year constitute a reasonable percentage of all the employees in the organization indicating that they understand issues to do with organizational operations.

\section{4.2.4 Highest level of education}

The researcher sought to find out the highest level of education of the respondents involved in the study. This was essential as the level of education indicates how easily an individual can comprehend things pertaining to their work. It also determines how easily an individual can respond to questions directed to them. The findings on highest level of education are relayed on the following table;

J. Table 4.4 Highest level of education

\begin{tabular}{|l|l|l|}
\hline Level & Frequency & Percentage \\
\hline Certificate & 12 & 25.0 \\
\hline Diploma & 25 & 52.1 \\
\hline Degree & 11 & 22.9 \\
\hline Total & & $\mathbf{1 0 0}$ \\
\hline
\end{tabular}

According to the findings on the table above, the study found out that $52.1 \%$ of the respondents had diplomas as their highest level of education, $25.0 \%$ had certificates while the least of the respondents, $22.9 \%$ had attained degree status. These findings 
indicated that the respondents reached by the study were people who had enough education to enable them comprehend the questions given to them by the researcher pertaining to strategic sourcing and organizational profitability.

\section{K. 4.3 Specific information}

L. 4.3.1 Effect of internal sourcing on organizational performance at the Acacia premier hotel Kisumu.

\section{The researcher sought to ascertain the effect of internal sourcing on organizational performance at the Acacia premier hotel, Kisumu.}

$N$. The findings are as presented on the following table;

O. Table 4.5: Effect of internal sourcing on organizational performance at the Acacia premier hotel, Kisumu.

P. S.A:- Strongly Agree A:-Agree U:-Undecided $\quad$ D:-Disagree S.D:- Strongly Agree

\begin{tabular}{|c|c|c|c|c|c|c|c|}
\hline & & S.A & $\mathbf{A}$ & $\mathbf{U}$ & D & S. D & Total \\
\hline \multirow{2}{*}{$\begin{array}{l}\text { Internal sourcing reduces the overall cost } \\
\text { of sourcing as a result improving } \\
\text { performance }\end{array}$} & Freq & 21 & 11 & 7 & 3 & 6 & 48 \\
\hline & $\%$ & 42.9 & 22.9 & 14.6 & 6.3 & 12.5 & 100 \\
\hline \multirow{2}{*}{$\begin{array}{l}\text { By using internal sourcing, an } \\
\text { organization is sure to get value for money }\end{array}$} & Freq & 9 & 17 & 10 & 5 & 7 & 48 \\
\hline & $\%$ & 18.8 & 35.4 & 20.8 & 10.4 & 14.6 & 100 \\
\hline \multirow{2}{*}{$\begin{array}{l}\text { Internally sourced services are more } \\
\text { efficient and reliable than when } \\
\text { outsourced }\end{array}$} & Freq & 16 & 8 & 6 & 9 & 9 & 48 \\
\hline & $\%$ & 33.3 & 16.7 & 12.5 & 18.8 & 18.8 & 100 \\
\hline
\end{tabular}

Basing on the findings relayed on the table 4.5 above, 21 (42.9\%) of all the respondents strongly agreed, 11 (22.9\%) agreed, 7 $(14.6 \%)$ were undecided, $3(6.3 \%)$ disagreed and $6(12.5 \%)$ of the respondents strongly disagreed that internal sourcing reduces the overall cost of sourcing as a result improving performance.

Further, $9(18.8 \%)$ of the respondents strongly agreed, 17 (35.4\%) agreed, 10 (20.8\%) were undecided, 5 (10.4) disagreed, and 7 $(14.6 \%)$ strongly disagreed that by using internal sourcing, an organization is sure to get value for money.

The respondents were also for the thought that internally sourced services are more efficient and reliable than when outsourced as was shown by $16(33.3 \%)$ of the respondents who strongly agreed, $8(16.7 \%)$ of the respondents who agreed, $6(12.5 \%)$ of the respondents who were undecided, as well as 9 (18.8\%) who disagreed and strongly disagreed respectively.

Q. 4.3.2 How outsourcing affects organizational performance at the Acacia premier hotel, Kisumu.

R. For the completion of this study, it was essential to ascertain how outsourcing affects organizational at Acacia premier Hotel, Kisumu. The findings are presented on the table following;

S. Table 4.6: How outsourcing affects organizational performance at the Acacia premier hotel, Kisumu.

S.A:- Strongly Agree A:- Agree U:-Undecided D:- Disagree S.D:- Strongly Agree

\begin{tabular}{|l|l|l|l|l|l|c|c|}
\hline \multicolumn{2}{|l|}{ S.A } & \multicolumn{1}{|c|}{ A } & U & D & S. D & Total \\
\hline Outsourcing ensures diversity in service & Freq & 17 & 19 & 1 & 6 & 5 & $\mathbf{4 8}$ \\
\hline
\end{tabular}




\begin{tabular}{|l|l|c|c|c|c|c|c|}
\hline $\begin{array}{l}\text { delivery and this ensures the achievement } \\
\text { of improved performance }\end{array}$ & \% & $\mathbf{3 5 . 4}$ & $\mathbf{3 9 . 6}$ & $\mathbf{2 . 1}$ & $\mathbf{1 2 . 5}$ & $\mathbf{1 0 . 4}$ & $\mathbf{1 0 0}$ \\
\hline $\begin{array}{l}\text { Through outsourcing, an organization is } \\
\text { able to reach its goals with ease leading to } \\
\text { improved performance }\end{array}$ & Freq & 19 & 13 & 5 & 9 & 2 & $\mathbf{4 8}$ \\
\cline { 2 - 8 } & $\%$ & $\mathbf{3 9 . 6}$ & $\mathbf{2 7 . 1}$ & $\mathbf{1 0 . 4}$ & $\mathbf{1 8 . 8}$ & $\mathbf{4 . 2}$ & $\mathbf{1 0 0}$ \\
\hline $\begin{array}{l}\text { Outsourced services are superior since } \\
\text { they are provided from outside the } \\
\text { organization, and by professionals }\end{array}$ & Freq & 13 & 8 & 13 & 5 & 9 & $\mathbf{4 8}$ \\
\cline { 2 - 8 } & $\%$ & $\mathbf{2 7 . 1}$ & $\mathbf{1 6 . 7}$ & $\mathbf{2 7 . 1}$ & $\mathbf{1 0 . 4}$ & $\mathbf{1 8 . 8}$ & $\mathbf{1 0 0}$ \\
\hline
\end{tabular}

The table above presents the findings on how outsourcing affects organizational performance at Acacia premier hotel Kisumu. From the findings, $17(35.4 \%)$ of the respondents strongly agreed that outsourcing ensures diversity in service delivery and this ensures the achievement of improved performance, 19 (39.6\%) agreed with the same, 1 (2.1\%) represented the undecided, 6 $(12.5 \%)$ disagreed and 5 (10.4\%) strongly disagreed.

The study also found out that 19 (39.6\%) of the respondents strongly agreed, $13(27.1 \%)$ agreed, $5(10.4 \%)$ were undecided, 9 $(18.8 \%)$ disagreed and $2(4.2 \%)$ strongly disagreed that through outsourcing, an organization is able to reach its goals with ease leading to improved performance

Further, $13(27.1 \%)$ of the respondents strongly agreed, 8 (16.7\%) agreed, $13(27.1 \%)$ were undecided, 5 (10.4\%) disagreed and 9 $(18.8 \%)$ of the respondents strongly disagreed that outsourced services are superior since they are provided from outside the organization, and by professionals.

T. 4.3.3 Effect of single sourcing on organizational performance at the Acacia premier hotel, Kisumu.

U. The study sought to find out the effect of single sourcing on organizational performance at the Acacia Premier Hotel, Kisumu. The findings were as relayed on the following table;

$V$. Table 4.7: Effect of single sourcing on organizational performance at the Acacia premier hotel, Kisumu.

W.S.A:- Strongly Agree A:-Agree U:-Undecided D:-Disagree S.D:- Strongly Agree

\begin{tabular}{|c|c|c|c|c|c|c|c|}
\hline & & S.A & $\mathbf{A}$ & $\mathbf{U}$ & D & S. D & Total \\
\hline \multirow{2}{*}{$\begin{array}{l}\text { Sourcing from a single provider ensures } \\
\text { that uniformity is achieved, which leads to } \\
\text { consistency in service delivery }\end{array}$} & Freq & 20 & 19 & 1 & 6 & 2 & 48 \\
\hline & $\%$ & 41.7 & 39.6 & 2.1 & 12.5 & 4.2 & 100 \\
\hline \multirow{2}{*}{$\begin{array}{l}\text { Single sourcing has the shortcoming of } \\
\text { loss diversity hence customers are given } \\
\text { recurrent services }\end{array}$} & Freq & 11 & 9 & 13 & 8 & 7 & 48 \\
\hline & $\%$ & 22.9 & 18.8 & 27.1 & 16.7 & 14.6 & 100 \\
\hline \multirow{2}{*}{$\begin{array}{l}\text { Single sourcing enables the building of } \\
\text { goodwill between the organization and its } \\
\text { providers and this can lead to reduced } \\
\text { costs }\end{array}$} & Freq & 25 & 17 & 1 & 2 & 3 & 48 \\
\hline & $\%$ & 52.1 & 35.4 & 2.1 & 4.2 & 6.3 & 100 \\
\hline
\end{tabular}


Basing on the findings on the table above, the researcher ascertained that sourcing from a single provider ensures that uniformity is achieved, which leads to consistency in service delivery. This was indicated by 20 (41.7\%) of the respondents who strongly agreed and $19(39.6 \%)$ of the respondents who agreed. On the same note, $1(2.1 \%)$ was undecided and $6(12.5 \%)$ disagreed as 2 $(4.2 \%)$ strongly disagreed with the statement.

The study also found out that $11(22.9 \%)$ of the respondents strongly agreed, 9 (18.8\%) of the respondents agreed, $13(27.1 \%)$ were undecided and $8(16.7 \%)$ disagreed and 7 (14.6\%) strongly disagreed that single sourcing has the shortcoming of loss diversity hence customers are given recurrent services.

The table also indicates that $25(52.1 \%)$ of the respondents strongly agreed, $17(35.4 \%)$ agreed, $1(2.1 \%)$ represented the undecided, $2(4.2 \%)$ disagreed and $3(6.3 \%)$ strongly disagreed that single sourcing enables the building of goodwill between the organization and its providers and this can lead to reduced costs.

Effect of multiple sourcing on organizational performance at the Acacia premier hotel, Kisumu.

\section{$X$. For the completion of this study, it was deemed important to find out the effect of multiple sourcing on organizational performance at the Acacia Premier Hotel, Kisumu.}

Y. Table 4.8: Effect of multiple sourcing on organizational performance at the Acacia premier hotel, Kisumu.

Z. S.A:- Strongly Agree A:-Agree U:-Undecided D:-Disagree S.D:- Strongly Agree

\begin{tabular}{|c|c|c|c|c|c|c|c|}
\hline & & S.A & $\mathbf{A}$ & $\mathbf{U}$ & D & S. D & Total \\
\hline \multirow{2}{*}{$\begin{array}{l}\text { Multiple sourcing gives room for the } \\
\text { achievement of organizational goals } \\
\text { within the right time frames leading to } \\
\text { improved performance }\end{array}$} & Freq & 16 & 15 & 8 & 4 & 5 & 48 \\
\hline & $\%$ & 33.3 & 31.3 & 16.7 & 8.3 & 10.4 & 100 \\
\hline \multirow{2}{*}{$\begin{array}{l}\text { Multiple sourcing has the shortcoming of } \\
\text { inconsistency which leads to reduced } \\
\text { satisfaction and performance }\end{array}$} & Freq & 20 & 19 & 2 & 6 & 1 & 48 \\
\hline & $\%$ & 41.7 & 39.6 & 4.2 & 12.5 & 2.1 & 100 \\
\hline \multirow{2}{*}{$\begin{array}{l}\text { By practicing multiple sourcing, } \\
\text { professionalism is improved since the } \\
\text { organization can choose from multiple } \\
\text { sources }\end{array}$} & Freq & 16 & 10 & 9 & 7 & 6 & 48 \\
\hline & $\%$ & 33.3 & 20.8 & 18.8 & 14.6 & 12.5 & 100 \\
\hline
\end{tabular}

The table indicates that Multiple sourcing gives room for the achievement of organizational goals within the right time frames leading to improved performance as was shown by $16(33.3 \%)$ of the respondents who strongly agreed and 15 (31.35\%) who agreed. This statement had $8(16.7 \%)$ of the respondents who were undecided while $4(8.3 \%)$ disagreed and $5(10.4 \%)$ strongly disagreed with the statement. 
The study also found out that $20(41.7 \%)$ of the respondents strongly agreed, $19(39.6 \%)$ agreed, $2(4.2 \%)$ were undecided, 6 $(12.5 \%)$ disagreed and $1(2.1 \%)$ strongly disagreed that multiple sourcing has the shortcoming of inconsistency which leads to reduced satisfaction and performance.

From the study findings, 16 (33.3\%) strongly agreed, 10 (20.8\%) agreed, 9 (18.8\%) were undecided, 7 (14.6\%) disagreed and 6 $(12.5 \%)$ strongly disagreed that By practicing multiple sourcing, professionalism is improved since the organization can choose from multiple sources.

\section{CHAPTER FIVE}

\section{A. 5.0 SUMMARY OF FINDINGS, CONCLUSION AND RECOMMENDATIONS}

\section{B. 5.1 Introduction}

This chapter contains the findings analyzed from the data collected. The findings are then further summarized here with a view to crystallize the specific findings in relation to the research objectives. The conclusion is then drawn from the findings in order to answer the research questions. The researcher then provides recommendations on what should be done.

\section{Summary of findings}

This section provides findings from the study basing on what the respondents reached by the study had to say about the study topic.

Basing on the findings, $42.9 \%$ of all the respondents strongly agreed, $22.9 \%$ agreed, $14.6 \%$ were undecided, $6.3 \%$ disagreed and $12.5 \%$ of the respondents strongly disagreed that internal sourcing reduces the overall cost of sourcing as a result improving performance. Further, $18.8 \%$ of the respondents strongly agreed, 35.4\% agreed, 20.8\% were undecided, 10.4 disagreed, and $14.6 \%$ strongly disagreed that by using internal sourcing, an organization is sure to get value for money.

The table above presents the findings on how outsourcing affects organizational performance at the ministry of lands, housing and urban development directorate of public works, Eldoret?. From the findings, $35.4 \%$ of the respondents strongly agreed that outsourcing ensures diversity in service delivery and this ensures the achievement of improved performance, $39.6 \%$ agreed with the same. The study also found out that $39.6 \%$ of the respondents strongly agreed, $27.1 \%$ agreed, $10.4 \%$ were undecided, $18.8 \%$ disagreed and $4.2 \%$ strongly disagreed that through outsourcing, an organization is able to reach its goals with ease leading to improved performance.

Basing on the findings on the table above, the researcher ascertained that sourcing from a single provider ensures that uniformity is achieved, which leads to consistency in service delivery. This was indicated by $41.7 \%$ of the respondents who strongly agreed and $39.6 \%$ of the respondents who agreed. The study also found out that $22.9 \%$ of the respondents strongly agreed, $18.8 \%$ of the respondents agreed, $27.1 \%$ were undecided and $16.7 \%$ disagreed and $14.6 \%$ strongly disagreed that single sourcing has the shortcoming of loss diversity hence customers are given recurrent services. 


\section{Conclusion}

Internal sourcing reduces the overall cost of sourcing as a result improving performance. By using internal sourcing, an organization is sure to get value for money

Internally sourced services are more efficient and reliable than when outsourced. Also, outsourcing ensures diversity in service delivery and this ensures the achievement of improved performance. Through outsourcing, an organization is able to reach its goals with ease leading to improved performance

Sourcing from a single provider ensures that uniformity is achieved, which leads to consistency in service delivery; Single sourcing has the shortcoming of loss diversity hence customers are given recurrent services

Multiple sourcing gives room for the achievement of organizational goals within the right time frames leading to improved performance; multiple sourcing has the shortcoming of inconsistency which leads to reduced satisfaction and performance.

\section{5.4 Recommendations}

The ministry should promote the use of sourcing in its transactions basing on the findings which point out that strategic sourcing contributes positively to organizational performance.

Structures should be put in place that accommodates strategic sourcing so that the ministry can realize improved performance generally.

\section{5.5 Suggestions for further study}

Research should be done on a similar topic but should be based on a manufacturing company.

\section{REFERENCES}

Al-Mudimigh, A.S., Zairi, \& Ahmed, A.M.M. (2004). Extending the concept of supply chain: The effective management of value chains. International Journal of Production Economics, 87, 309-320.

Bradely, J. F (1994)., “Administrative Financial Management”, New York, Branves and Noble.

Carr. A.S., \& Smeltzer, L.R. (2000). An empirical study of the relationships among purchasing skills and strategic sourcing financial performance, and supplier responsiveness. The Journal of Supply Chain Management.

Carter, J.R., \& Narasimhan, R. (1994) The role of purchasing and materials management in total quality management and customer satisfaction International Journal of Purchasing and Materials Management Summer, 3-13

Chopra, S. \& Meindl, P. (2003) Supply Chain Management: Strategy, planning and operations Upper Saddle River, New Jersey: Pearson Prentice Hall

Court B, \& Steele P. (1997). Profitable Purchasing Strategies: a manager's guide for improving organizational competitiveness through the skills of purchasing. McGraw-Hill Book Company England

Daniel B. (2008): Cooperative sourcing: Simulation studies and empirical data on outsourcing coalitions in the banking industry. Gabler, Wiesbaden .

Dobler D. W, Burt N. (1996).Purchasing and supply management, 6th edition, New Delhi, McGraw Hill Publishing Company Limited. 
Ellram, L.M., Zsidisin, G.A., Siferd, S.P., \& Stanly, M.J. (2002) The impact of purchasing and supply management activities on corporate success The Journal of Supply Chain Management

Fine, C. (1998) Clockspeed: Winning Industry Control in the Age of Temporary Advantage New York: Persus Books.

Foddy, W. (2001) Constructing questions for interviews and questionnaires; Theory and practice in social research. Cambridge: Cambridge University Press.

Freeman, V.T., \& Cavinato, J.L. (1990). Fitting purchasing to the strategic firm: frameworks, processes, and values. Journal of Purchasing \& Materials Management, 26(1), 6-10.

Gerd K.(2005) The Bermuda Triangle of Business Wiley-VCH, Weinheim Düsseldorf.

Gunasekaran, A., Patel, C., \& McGaughey, R.E. (2004). A framework for supply chain performance measurement. International Journal of Production Econlomics, 87, 333-347.

James C. Van Horne \& John M. Wachowicz, Jr (2005), “Fundamentals of Financial Management”, Indian Branch, Delhi, Pearson Education (Singapore) Pte. Ltd

Kannan, V.R., \& Tan, K.C. (2002). Supplier selection and assessment: Their impact on business performance. The Journal of Supply Chain Management, Fall, 11-21.

Kombo, D.K. \& Tromp, D.L.A. (2006): Proposal and Thesis Writing:AnIntroduction Africa, Nairobi Paulines Publications

Kothari, C. R (2007): Research Methodology, 2ndEd. New Delhi,India, Wishwa, Prakashan,.

Kothari, C. R (1999): Research Methodology, methods and techniques. India, K.K. Gupta.

Koulopoulos, Thomas. (2006a) Value Creation Through Smart-Sourcing. Value Creation Through Smart-Sourcing, March 2006, Issue 53

Koulopoulos, Thomas. (2006b) Smartsourcing: Driving Innovation Through Outsourcing. Platinum Press.

Krause, D.R., Scannell, T.V., \& Calantone, R.J. (2000). A structural analysis of the effectiveness of buying firms' strategies to improve supplier performance. Decision Sciences, 31(1), 33-55.

Mugenda, M.O, \& Mugenda G.A. (1999). Research Methods: Quantitative andQualitative Approaches. Nairobi: ACTS Press

Mugenda, M.O, \& Mugenda G.A. (2003). Research Methods: Quantitative andQualitative Approaches. Nairobi: ACTS Press

Narasimhan, R., \& Das, A. (2001). The impact of purchasing integration and practices on manufacturing performance. Journal of Operations Management, 19, 593-609.

Nishiguchi, Toshihiro. Strategic Industrial Sourcing (New York: Oxford University, 1994) ISBN 0-19-507109-3

Pandey M (1993), “Financial Management”, 2002, Vikas Publishing House Pvt. Ltd., New Delhi. S. C. Kuchhal, “Financial Management - An Analytical and Conceptual Approach”, Chaitanya Publishing House, Allahabad, 1993.

Patton, M. Q. (2002).Qualitative evaluation and research methods. (3rd Ed.) NewburyPark, Cal.: Sage Publications. 
Porter, M. E. (1980) Competitive strategy: techniques for analyzing industries and competitors New York City, New York: Free Press

Saunders, M., Lewis, P. \& Thornhill, A. (2009). Research Methods for Business students, $5^{\text {th }}$ edition. Essex, England, Pearson Education Limited.

Schuh C. (2009): The Purchasing Chessboard: 64 Methods to Reduce Cost and Increase Value with Suppliers. Springer, Berlin Heidelberg

Shin, H., Collier, D.A., \& Wilson, D.D. (2000) Supply management orientation and supplier/buyer performance Journal of Operations Management18, 317-333

Tan, K.C. (2002) Supply chain management: Practices, concerns, and performance issues The Journal of Supply Chain Management Winter 42-53.

Zenz G. J. (1994). Purchasing and the Management of Materials. USA Articles. John Wiley and Sons Inc

\section{APPENDIX I}

\section{QUESTIONNAIRE}

I am a student University of Eldoret and I am carrying out a study on the effect of strategic sourcing on organizational performance. For this reason, I am hereby requesting you to take part in this study by appropriately filling in the required information in the questionnaire.

Your participation is of great importance to this study since it will enable me to achieve the objectives of the study.

The questionnaire is aimed at collecting data for purely academic purposes.

Do not write your name anywhere in this paper.

\section{PART A: DEMOGRAPHIC DATA OF RESPONDENTS}

1. Age bracket

20-30 years [ ]
$41-50$ ears [ ]

2. Gender

Male [ ] Female [ ]

3. Indicate your highest level of education (please tick as appropriate)

Secondary [ ] Certificate [ ]

Diploma [ ] Degree [ ]

4. For how long have you worked here?

Less than 5 years [ ] 6-8 years [ ] 

9- 11 years
[ ]
12 years and above [ ]

\section{SECTION B: SPECIFIC INFORMATION}

\section{Effect of internal sourcing on organizational performance}

To what extent do you agree with the following statements on the effect of internal sourcing on organizational performance at the Acacia Premier Hotel, Kisumu?

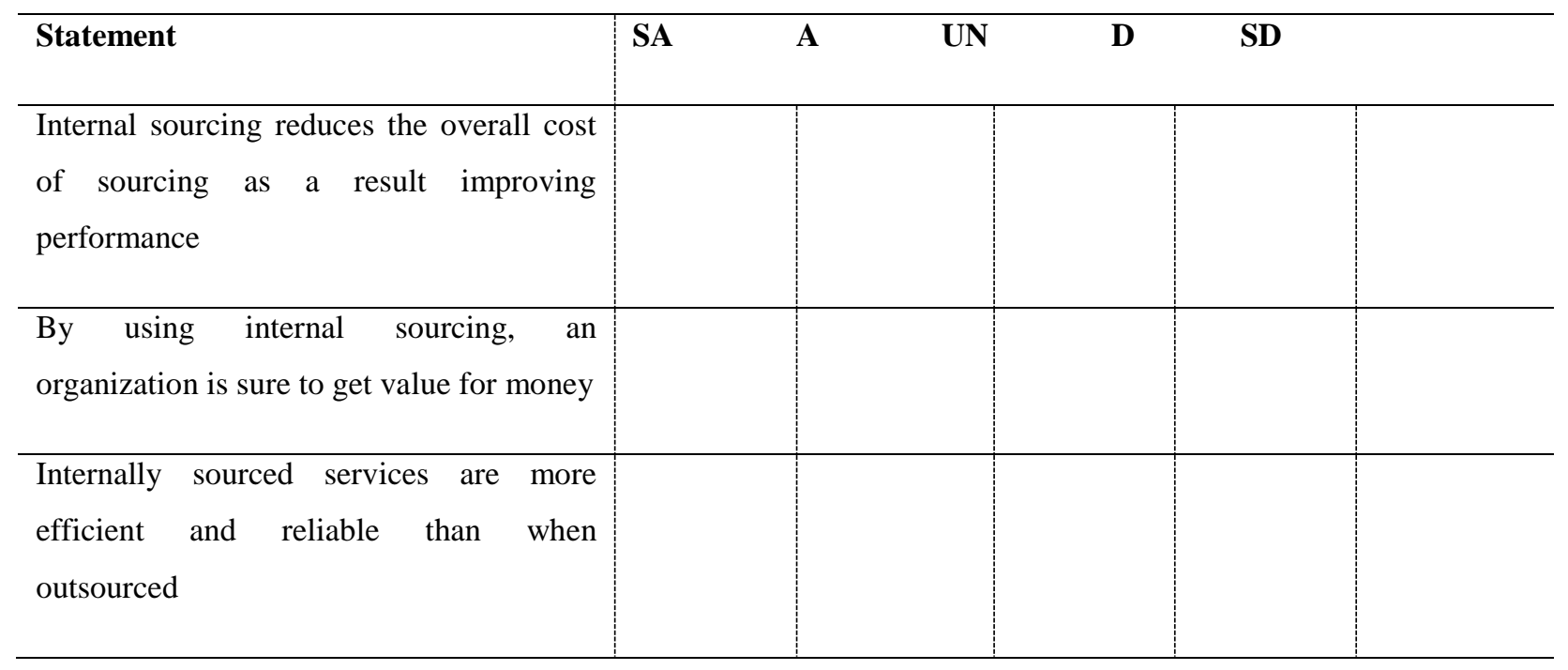

Please give more information on this;

\section{Effect of outsourcing on organizational performance}

To what extent do you agree with the following statements on how outsourcing affects organizational performance at the Acacia Premier Hotel, Kisumu?

\begin{tabular}{l|l|l|l|l|l}
\hline Statement & SA & A & UN & \multicolumn{1}{c}{ D } \\
\hline $\begin{array}{l}\text { Outsourcing ensures diversity in service } \\
\text { delivery and this ensures the achievement }\end{array}$ & & & & & \\
of improved performance & & & & & \\
& & & & & \\
\hline
\end{tabular}




\begin{tabular}{l|l|l|l|l|l}
\hline Through outsourcing, an organization is & & & & \\
able to reach its goals with ease leading to & & & & \\
improved performance & & & & \\
\hline Outsourced services are superior since & & & & \\
they are provided from outside the \\
organization, and by professionals
\end{tabular}

Please give more information on this;

\section{Effect of single sourcing on organizational performance}

To what extent do you agree with the following statements on the effect of single sourcing on organizational performance at the Acacia Premier Hotel, Kisumu.

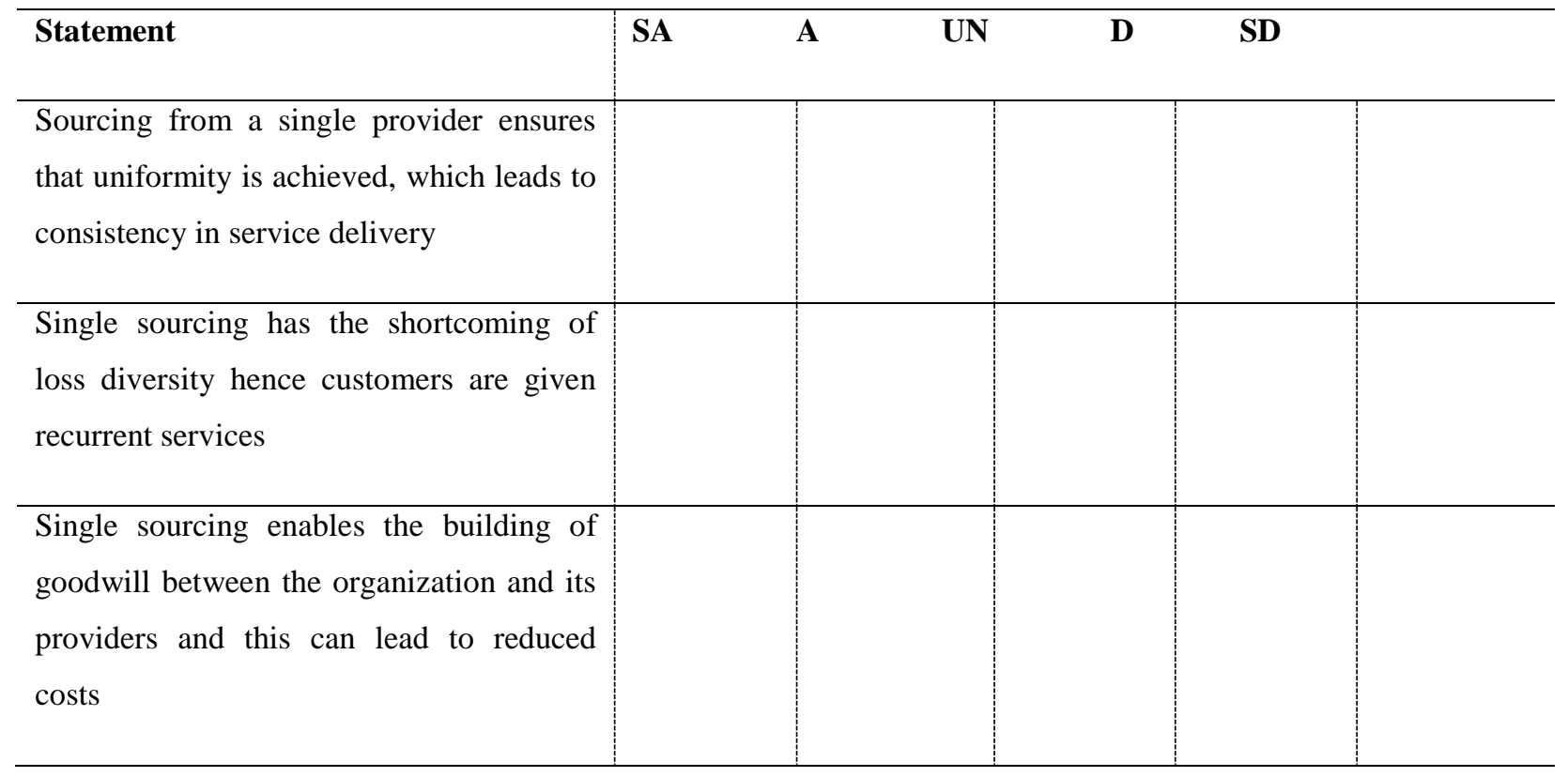

Please give more information on this; 


\section{Effect of multiple sourcing on organizational performance}

To what extent do you agree with the following statements on the effect of multiple sourcing on organizational performance at the Acacia Premier Hotel, Kisumu.

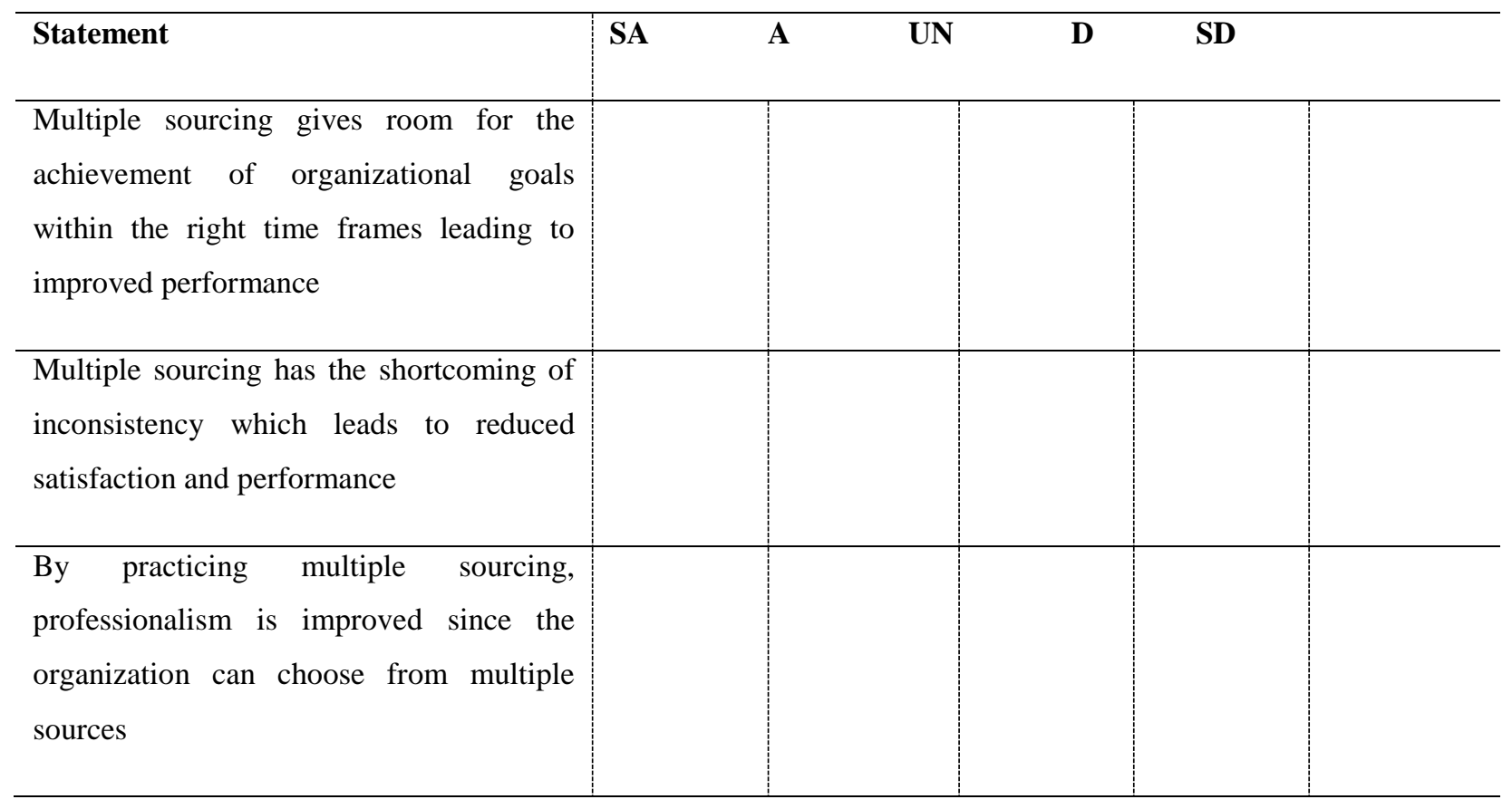


